\title{
ABNORMALITY OF THE BLOOD-CEREBROSPINAL FLUID BARRIER OF PATIENTS SUFFERING FROM A DEPRESSIVE ILLNESS
}

\author{
BY \\ A. J. COPPEN \\ From the Institute of Psychiatry, Maudsley Hospital, London
}

The concept of the blood-brain and bloodcerebrospinal fluid barrier is based on numerous observations that many substances pass from the blood into the central nervous system very much more slowly than they do into other organs. At first these observations were concerned with "foreign" substances such as vital dyes but more recently, with the use of radioactive isotopes, physiologically important ions and molecules have been shown to be influenced by a similar "barrier" effect in their rate of entry into the nervous system. It is probable that these "barriers" represent mechanisms for ensuring the stability of the internal environment in which neurons function and that they are in consequence of the greatest importance for the normal functioning of the central nervous system.

There have therefore been many investigations of the blood-cerebrospinal fluid barrier in patients suffering from nervous and mental disease. These have been mostly by means of the Walter (1929) bromide ratio test, which measures the steady-state distribution ratio of bromide between blood and cerebrospinal fluid after the administration of sodium bromide. This test, however, for various reasons has not been found to be satisfactory (Coppen, 1959) and, as Davson (1956) shows, permeability of this barrier is best determined by measuring the rate of entry of a substance from the blood into the cerebrospinal fluid rather than by measuring the steady-state distribution ratio.

I report in the present paper an investigation into the blood-cerebrospinal fluid barrier of mental patients as measured by the rate of entry into the cerebrospinal fluid of ${ }^{24} \mathrm{Na}$ and also, in some of the patients, tritiated water.

\section{The Investigation}

Five groups of patients were tested, the purpose and the nature of the test having been explained to them. The control group consisted of 12 patients who were given a spinal anaesthetic for abdominal operations, either for peptic ulcer or carcinoma of the bowel. Only patients in whom the diagnosis appeared unequivocal were selected for testing and the diagnostic criteria used followed those described by Mayer-Gross, Slater, and Roth (1954) in their textbook of psychiatry. Nineteen schizophrenic patients were tested, 12 of whom had been in hospital under a year and are described as acute schizophrenia; the remainder had been in hospital for at least five years and are described as chronic schizophrenia. Three groups of depressed patients were tested, namely, 20 patients who were tested before treatment; 10 patients who had been depressed but had recovered or substantially improved; 11 patients who were still $\bar{C}$ depressed in spite of being treated with at least five $\rho$ electrically-induced convulsions, the last treatment being within a fortnight of the test.

No patient had received physical treatment within six months or tranquillizing drugs within three months of the test unless otherwise stated.

The Test.-The patient under test was given 100 microcuries ${ }^{24} \mathrm{Na}$ intravenously in the form of an isotonic solution of sodium chloride. Blood samples (obtained from the opposite arm) were then taken at the following minutes after the injection of ${ }^{24} \mathrm{Na}$ : five, 15, 30, 45 and following the lumbar puncture which was performed at 60 minutes. Ten millilitres of cerebrospinal fluid were removed for testing. To avoid repeated venepuncture blood was obtained through an indwelling Gordh needle and was kept from clotting by small

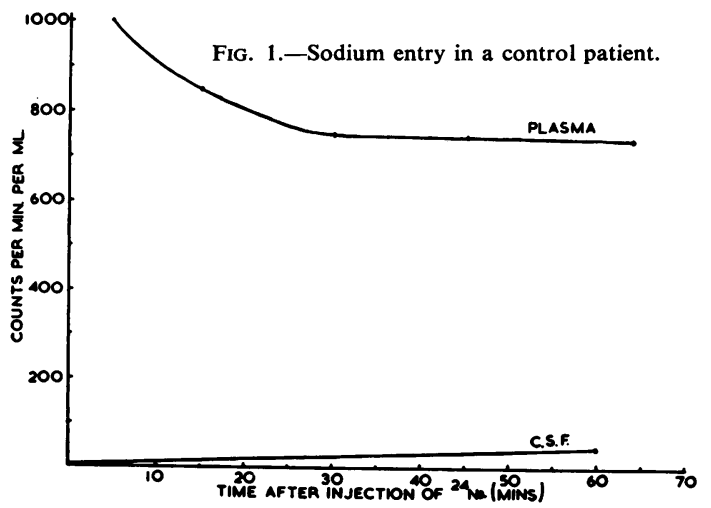


amounts of heparin. A typical record is shown in Fig. 1. The data of Sweet, Selverstone, Soloway, and Stetten (1951) show that the rise in lumbar ${ }^{24} \mathrm{Na}$ concentration for the first hour after its intravenous injection follows approximately a straight line.

Rate of entry may be presented as a simple ratio:$\frac{\text { C.S.F. concentration of }{ }^{24} \mathrm{Na}\left(\mathrm{C}_{\mathrm{c} . \text { s.f. }}\right)}{\text { Plasma concentration of }{ }^{24} \mathrm{Na}\left(\mathrm{C}_{\mathrm{pl}}\right)} \times 100$, at one hour

This expression has the disadvantage of not taking into account the varying blood levels of ${ }^{24} \mathrm{Na}$ during the interval between its administration and the lumbar puncture. Thus a better measure of the rate of entry will be given by the parameter $\mathrm{k}$ in the equation.

$$
\frac{\mathrm{d} \mathrm{C}_{\text {c.s.f. }}}{\mathrm{d} \mathrm{t}}=\mathrm{k}_{\mathrm{in}} \mathrm{C}_{\mathrm{pl}}-\mathrm{k}_{\text {out }} \mathrm{C}_{\text {c.s.f. }}
$$

which can be computed by a graphical integration (Davson and Luck, 1959). The units of this transfer constant $k_{\text {in }}$ are reciprocals of time and will be expressed in so many $\min .^{-1}$

In some patients the entry of isotopic water containing tritium was measured at the same time as entry of ${ }^{24} \mathrm{Na}$. Thirty minutes after the injection of ${ }^{24} \mathrm{Na} 0.5$ millicurie tritiated water $(0.5 \mathrm{ml}$. made up to $4 \mathrm{ml}$. with isotonic saline) was injected intravenously and a blood sample was obtained five minutes later. Otherwise the test was carried out as above. Tritium entry is expressed in two ways: (1) Following Bering (1952) as the half time for cerebrospinal fluid to reach the plasma tritium concentration; (2) as a transfer constant obtained as for the entry of ${ }^{24} \mathrm{Na}$.

${ }^{24} \mathrm{Na}$ was estimated in a well-type scintillation counter and where necessary corrections were made for background, decay, and resolving time. Tritium was estimated using a liquid scintillation counter by the method described by Langham, Eversole, Hayes, and Trujillo (1956). In the calculation of the results corrections were applied for the greater specific gravity of plasma.

\section{Results}

Sodium Entry.-The results are given in Tables $\mathrm{I}-\mathrm{V}$, both as the transfer constant $\mathbf{k}_{\text {in }}$ and to facilitate comparison with other work, as the ratio at one hour.

TABLE I

SODIUM ENTRY IN THE CONTROL GROUP

\begin{tabular}{|c|c|c|c|c|}
\hline Diagnosis & Sex & Age & One-hour Ratio & $k_{\text {in }}\left(\min .^{-1}\right)$ \\
\hline Carcinoma of colon & $\begin{array}{l}\mathbf{F} \\
\mathbf{M}\end{array}$ & $\begin{array}{l}54 \\
59\end{array}$ & $\begin{array}{l}4 \cdot 5 \\
3 \cdot 0\end{array}$ & $\begin{array}{l}0.00071 \\
0.00040\end{array}$ \\
\hline Peptic ulcer & $\begin{array}{l}\mathbf{M} \\
\mathbf{M} \\
\mathbf{M} \\
\mathbf{M} \\
\mathbf{M} \\
\mathbf{M} \\
\mathbf{M} \\
\mathbf{M} \\
\mathbf{M} \\
\mathbf{M}\end{array}$ & $\begin{array}{l}47 \\
41 \\
32 \\
34 \\
52 \\
51 \\
66 \\
66 \\
64 \\
60\end{array}$ & $\begin{array}{l}3 \cdot 6 \\
4 \cdot 5 \\
4 \cdot 7 \\
6 \cdot 1 \\
2 \cdot 3 \\
3 \cdot 4 \\
3 \cdot 0 \\
3 \cdot 9 \\
4 \cdot 1 \\
4 \cdot 1\end{array}$ & $\begin{array}{l}0.00054 \\
0.00075 \\
0.00076 \\
0.00098 \\
0.00040 \\
0.00054 \\
0.00045 \\
0.00065 \\
0.00062 \\
0.00061\end{array}$ \\
\hline Mean & & $52 \cdot 1$ & 3.9 & 0.00062 \\
\hline Standard deviation & & $12 \cdot 9$ & 0.98 & 0.00017 \\
\hline
\end{tabular}

TABLE II

SODIUM ENTRY IN GROUP OF DEPRESSED PATIENTS

\begin{tabular}{|c|c|c|c|c|}
\hline Diagnosis & Sex & Age & One-hour Ratio & $k_{\text {in }}\left(\min .^{-1}\right)$ \\
\hline Depression & $\begin{array}{l}\mathbf{M} \\
\mathbf{M} \\
\mathbf{F} \\
\mathbf{M} \\
\mathbf{M} \\
\mathbf{F} \\
\mathbf{M} \\
\mathbf{M} \\
\mathbf{M} \\
\mathbf{M} \\
\mathbf{M} \\
\mathbf{M} \\
\mathbf{F} \\
\mathbf{M} \\
\mathbf{F} \\
\mathbf{M} \\
\mathbf{M} \\
\mathbf{F} \\
\mathbf{M} \\
\mathbf{F}\end{array}$ & $\begin{array}{l}35 \\
44 \\
51 \\
53 \\
29 \\
46 \\
53 \\
68 \\
46 \\
53 \\
49 \\
64 \\
38 \\
50 \\
33 \\
59 \\
40 \\
56 \\
36 \\
39\end{array}$ & $\begin{array}{l}1.8 \\
1.7 \\
1.4 \\
3.0 \\
2.4 \\
3.0 \\
2.6 \\
3.0 \\
2.2 \\
2.7 \\
2.2 \\
2.2 \\
1.7 \\
1.9 \\
2.9 \\
1.6 \\
3.2 \\
3.6 \\
3.1 \\
3.6\end{array}$ & $\begin{array}{l}0.00028 \\
0.00023 \\
0.00020 \\
0.00048 \\
0.00036 \\
0.00048 \\
0.00042 \\
0.00045 \\
0.00034 \\
0.00039 \\
0.00033 \\
0.00031 \\
0.00027 \\
0.00031 \\
0.00045 \\
0.00019 \\
0.00049 \\
0.00053 \\
0.00049 \\
0.00051\end{array}$ \\
\hline Mean & & $47 \cdot 1$ & $2 \cdot 7$ & 0.00038 \\
\hline Standard deviation & & $7 \cdot 5$ & 0.67 & 0.00011 \\
\hline \multirow[t]{2}{*}{$\begin{array}{l}\text { Difference from } \\
\text { control group }\end{array}$} & $\mathbf{t}$ & $1 \cdot 19$ & $4 \cdot 14$ & $6 \cdot 60$ \\
\hline & $\mathbf{P}$ & $\begin{array}{c}\text { Not } \\
\text { signifi- } \\
\text { cant }\end{array}$ & $<0.001$ & $<0.001$ \\
\hline
\end{tabular}

*Cerebral thrombosis four years ago. Hypertension.

TABLE III

SODIUM ENTRY IN SCHIZOPHRENIA

\begin{tabular}{|c|c|c|c|c|}
\hline Diagnosis & Sex & Age & One-hour Ratio & $\mathbf{k}_{\text {in }}\left(\min .^{-1}\right)$ \\
\hline $\begin{array}{l}\text { Acute schizophrenia } \\
\text { Chronic schizophrenia }\end{array}$ & $\begin{array}{l}\mathbf{M} \\
\mathbf{F} \\
\mathbf{M} \\
\mathbf{M} \\
\mathbf{M} \\
\mathbf{F} \\
\mathbf{F} \\
\mathbf{F} \\
\mathbf{F} \\
\mathbf{M} \\
\mathbf{F} \\
\mathbf{M} \\
\mathbf{F} \\
\mathbf{F} \\
\mathbf{F} \\
\mathbf{F} \\
\mathbf{F} \\
\mathbf{F} \\
\mathbf{F}\end{array}$ & $\begin{array}{l}43 \\
47 \\
24 \\
34 \\
19 \\
23 \\
42 \\
37 \\
37 \\
37 \\
38 \\
38 \\
58 \\
44 \\
44 \\
49 \\
60 \\
36 \\
60\end{array}$ & $\begin{array}{l}4 \cdot 4 \\
4 \cdot 0 \\
3 \cdot 8 \\
7 \cdot 1 \\
6 \cdot 6 \\
2 \cdot 7 \\
5 \cdot 3 \\
2 \cdot 4 \\
2 \cdot 6 \\
3 \cdot 9 \\
3 \cdot 6 \\
4 \cdot 8 \\
4 \cdot 6 \\
3 \cdot 6 \\
4 \cdot 5 \\
3 \cdot 4 \\
2 \cdot 7 \\
2 \cdot 4 \\
3 \cdot 4 \\
\end{array}$ & $\begin{array}{l}0.00070 \\
0.00064 \\
0.00064 \\
0.00120 \\
0.00105 \\
0.00043 \\
0.00091 \\
0.00033 \\
0.00038 \\
0.00064 \\
0.00054 \\
0.00071 \\
0.00065 \\
0.00056 \\
0.00065 \\
0.00048 \\
0.00041 \\
0.00037 \\
0.00044\end{array}$ \\
\hline Mean & & $40 \cdot 5$ & $4 \cdot 0$ & 0.00061 \\
\hline Standard deviation & & $11 \cdot 2$ & $1 \cdot 3$ & 0.00023 \\
\hline \multirow[t]{2}{*}{$\begin{array}{l}\text { Difference from } \\
\text { control group }\end{array}$} & $\mathbf{t}$ & $2 \cdot 8$ & 0.22 & $0 \cdot 16$ \\
\hline & $\mathbf{P}$ & $<0.01$ & $\begin{array}{l}\text { Not } \\
\text { significant }\end{array}$ & $\begin{array}{l}\text { Not } \\
\text { significant }\end{array}$ \\
\hline
\end{tabular}

The results fall into two main classes. First there are the groups of patients who are not suffering from a depressive illness: these are the control and schizophrenic groups and the group of patients who have recovered from a depressive illness. These groups have mean transfer constants (and one-hour ratios) of $0.00062(3.9 \%), 0.00061(4.0 \%)$, and $0.00062(3.8 \%)$ respectively. The second class of 
TABLE IV

SODIUM ENTRY IN THE GROUP OF PATIENTS RECOVERED FROM A DEPRESSIVE ILLNESS

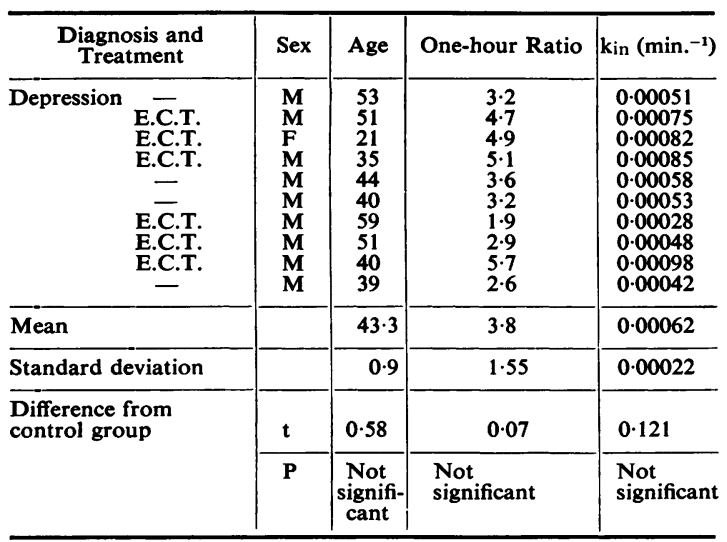

TABLE V

SODIUM ENTRY IN PATIENTS NOT RESPONDING TO E.C.T.

\begin{tabular}{|c|c|c|c|c|c|}
\hline \multicolumn{2}{|l|}{ Diagnosis } & Sex & Age & One-hour Ratio & $\mathrm{k}_{\text {in }}\left(\min .^{-1}\right)$ \\
\hline \multicolumn{2}{|c|}{$\begin{array}{l}\text { Depression and no } \\
\text { response to E.C.T. }\end{array}$} & $\begin{array}{l}\mathbf{M} \\
\mathbf{M} \\
\mathbf{M} \\
\mathbf{F} \\
\mathbf{M} \\
\mathbf{M} \\
\mathbf{F} \\
\mathbf{M} \\
\mathbf{M} \\
\mathbf{F} \\
\mathbf{M}\end{array}$ & $\begin{array}{l}50 \\
33 \\
26 \\
49 \\
59 \\
53 \\
42 \\
46 \\
47 \\
36 \\
46\end{array}$ & $\begin{array}{l}1.6 \\
1.7 \\
3.1 \\
1.9 \\
1.8 \\
2.7 \\
2.7 \\
3.0 \\
2.5 \\
2.7 \\
2.6\end{array}$ & $\begin{array}{l}0.00028 \\
0.00027 \\
0.00041 \\
0.00033 \\
0.00027 \\
0.00040 \\
0.00040 \\
0.00046 \\
0.00035 \\
0.00040 \\
0.00037\end{array}$ \\
\hline \multicolumn{2}{|l|}{ Mean } & & $44 \cdot 3$ & $2 \cdot 4$ & 0.00036 \\
\hline \multicolumn{2}{|c|}{ Standard deviation } & & $9 \cdot 5$ & 0.54 & 0.00006 \\
\hline \multirow[t]{2}{*}{$\begin{array}{l}\text { Difference from } \\
\text { control group }\end{array}$} & $\mathbf{t}$ & & $1 \cdot 77$ & $5 \cdot 0$ & $4 \cdot 85$ \\
\hline & $\mathbf{P}$ & \multicolumn{2}{|c|}{$\begin{array}{l}\text { Not } \\
\text { significant }\end{array}$} & 0.001 & 0.001 \\
\hline
\end{tabular}

TABLE VI

RESULTS IN PATIENTS TESTED TWICE

\begin{tabular}{|c|c|c|c|c|c|c|c|c|}
\hline Age & Sex & Diagnosis & $\begin{array}{l}\text { One-hour } \\
\text { Ratio }\end{array}$ & $\operatorname{kin}\left(\min .^{-1}\right)$ & Treatment & $\begin{array}{l}\text { Condition } \\
\text { on Re-test }\end{array}$ & $\begin{array}{c}\text { One-hour } \\
\text { Ratio }\end{array}$ & $\operatorname{kin}\left(\min .^{-1}\right)$ \\
\hline $\begin{array}{l}50 \\
38 \\
46 \\
40 \\
53 \\
59\end{array}$ & $\begin{array}{l}\mathbf{M} \\
\mathbf{F} \\
\mathbf{M} \\
\mathbf{M} \\
\mathbf{M}^{*}\end{array}$ & $\begin{array}{l}\text { Depression } \\
\text { Depression } \\
\text { Depression } \\
\text { Depression } \\
\text { Depression } \\
\text { Depression }\end{array}$ & $\begin{array}{l}1.9 \\
1.7 \\
2.2 \\
3.2 \\
2.6 \\
1.6\end{array}$ & $\begin{array}{l}0.00031 \\
0.00027 \\
0.00034 \\
0.00049 \\
0.00042 \\
0.00019\end{array}$ & $\begin{array}{l}\text { E.C.T. } \\
\text { E.C.T. } \\
\text { E.C.T. } \\
\text { E.C.T. } \\
\text { E.C.T. }\end{array}$ & $\begin{array}{l}\text { Unimproved } \\
\text { Unimproved } \\
\text { Unimproved } \\
\text { Improved } \\
\text { Improved } \\
\text { Improved }\end{array}$ & $\begin{array}{l}1 \cdot 6 \\
1 \cdot 7 \\
2 \cdot 6 \\
5 \cdot 7 \\
3 \cdot 2 \\
1 \cdot 9\end{array}$ & $\begin{array}{l}0.00028 \\
0.00027 \\
0.00037 \\
0.00098 \\
0.00051 \\
0.00028\end{array}$ \\
\hline
\end{tabular}

*Cerebral thrombosis four years ago. Hypertension.

patients are those suffering from a depressive illness, one group before treatment the other group after electroconvulsive therapy (E.C.T.). These two groups have mean entry rates nearly half that of the other groups, namely $0.00038(2.7 \%)$ and 0.00036 $(2.4 \%)$ respectively. Statistical comparison shows that the two groups of depressed patients differ significantly from the control group. The groups, with the exception of the schizophrenic group, show no significant difference with respect to age.

Table VI shows the results on the small number of patients who were re-tested. These results are in line with those found for the groups, that is, the patients who had improved on re-test have increased rates of penetration in contrast to those who did not improve and showed no appreciable change in sodium entry.

Tritium Entry.-Table VII shows the results obtained in the two groups of patients who were tested: (a) Patients suffering from a depressive illness and $(b)$ patients who had recovered from a depressive illness. There is little difference between the rates of entry of tritium in the two groups, being slightly less in the depressed group. The one patient who was re-tested on recovery showed a rate of entry
TABLE VII

TRITIUM ENTRY

\begin{tabular}{|c|c|c|c|c|}
\hline \multirow{2}{*}{ Sex } & \multirow{2}{*}{ Age } & \multicolumn{2}{|c|}{ Tritium Entry } & \multirow{2}{*}{$\begin{array}{l}\text { Sodium Entry } \\
\left(\mathrm{k}_{\mathrm{in}}\left(\mathrm{min}^{-1}\right)\right.\end{array}$} \\
\hline & & Half Time (min.) & $k_{\text {in }}\left(\min .^{-1}\right)$ & \\
\hline \multicolumn{4}{|c|}{ 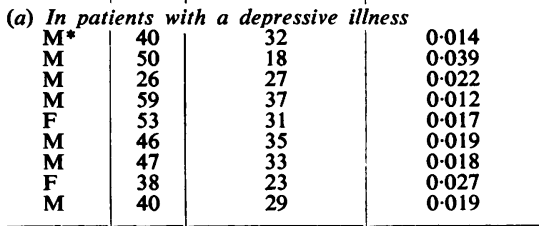 } & $\begin{array}{l}0.00049 \\
0.00027 \\
0.00040 \\
0.00027 \\
0.00040 \\
0.00046 \\
0.00035 \\
0.00040 \\
0.00037\end{array}$ \\
\hline Mean & $44 \cdot 3$ & $29 \cdot 4$ & 0.021 & 0.00038 \\
\hline $\begin{array}{l}\text { Standard } \\
\text { deviation }\end{array}$ & $9 \cdot 6$ & $6 \cdot 0$ & 0.008 & $0 \cdot 00008$ \\
\hline \multicolumn{4}{|c|}{\begin{tabular}{l|l|l|c} 
(b) In patients recovered from a depressive illness \\
M* & 40 & 32 & 0.013 \\
M & 40 & 26 & 0.022 \\
M & 4 & 27 & 0.022 \\
M & 51 & 20 & 0.029 \\
M & 39 & 18 & 0.039 \\
M & 53 & 24 & 0.025 \\
M & 51 & 23 & 0.027 \\
\end{tabular}} & $\begin{array}{l}0.00098 \\
0.00053 \\
0.00058 \\
0.00048 \\
0.00042 \\
0.00051 \\
0.00075\end{array}$ \\
\hline Mean & $45 \cdot 4$ & $24 \cdot 3$ & 0.025 & 0.00061 \\
\hline $\begin{array}{l}\text { Standard } \\
\text { deviation }\end{array}$ & $6 \cdot 1$ & $4 \cdot 7$ & 0.008 & 0.00019 \\
\hline $\begin{array}{l}\text { Difference } \\
\text { from } \\
\text { group }(a)\end{array}$ & $\begin{array}{l}\mathbf{t} \\
\mathbf{P}\end{array}$ & $\begin{array}{c}1.8 \\
\text { Not significant }\end{array}$ & $\begin{array}{c}1 \cdot 13 \\
\text { Not significant }\end{array}$ & $\begin{array}{r}3.3 \\
<0.01\end{array}$ \\
\hline
\end{tabular}

*The same patient tested when ill and when recovered. 
of sodium that was practically double the rate when he was depressed; in spite of this the rate of entry of tritium was substantially unchanged.

\section{Factors Affecting the Test}

The rate of entry of ${ }^{24} \mathrm{Na}$ varies along the neural axis, being highest in the ventricles and lowest in the lumbar region (Sweet et al., 1951). It was therefore important to know how much successive samples of cerebrospinal fluid differed, for although every care was taken to collect the first $10 \mathrm{ml}$. it is inevitable that there was a small but variable loss of fluid before its collection.

Table VIII shows the concentration of ${ }^{24} \mathrm{Na}$ in successive samples of cerebrospinal fluid. The concentration increases with each sample, rising steeply after $10 \mathrm{ml}$. However, as the initial loss never exceeded $1 \mathrm{ml}$. and in most cases was considerably less, this factor could not be responsible for the considerable differences found between the groups.

TABLE VIII

EFFECTS OF COUGHING AND EXERCISE ON SAMPLES OF CEREBROSPINAL FLUID

\begin{tabular}{c|c|c|c|c}
\hline Case & $\begin{array}{c}\text { Sample } \\
\text { No. }\end{array}$ & $\begin{array}{c}\text { Volume } \\
\text { (ml.) }\end{array}$ & $\begin{array}{c}\text { Counts/ } \\
\text { min./ml. }\end{array}$ & $\begin{array}{c}\% \text { Increase } \\
\text { over } \\
\text { First Sample }\end{array}$ \\
\hline
\end{tabular}

Variation of count rate with withdrawal of successive samples of C.S.F.

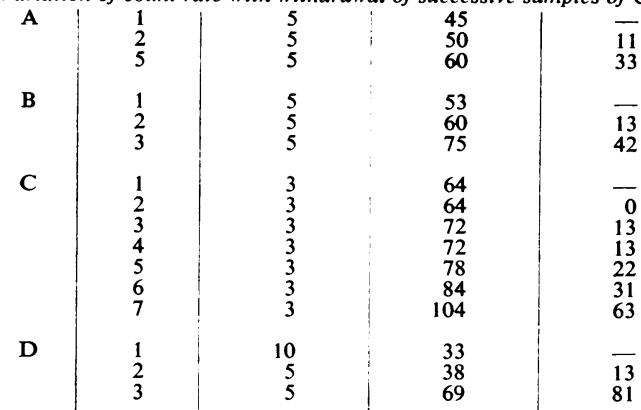

Effect of coughing between sample 1 and sample 2 on count rates.

$\left|\begin{array}{l|}1 \\ 2\end{array}\right|$

F

$\begin{array}{lr}5 & 69 \\ 5 & 75\end{array}$

\begin{tabular}{l|l}
69 & \\
75 & 9
\end{tabular}

\begin{tabular}{l|l|l}
1 & 5 \\
2 & 5
\end{tabular}

G

5
5

5

66
72

165
171

Effect of physical exercise on sodium entry in two depressed patients. Case $\mathbf{H} \quad \mathbf{k}=0.00036$

$\left.\begin{array}{ll}\mathbf{H} & \mathbf{k}=0.00036 \\ \text { I } & \mathbf{k}=0.00048\end{array}\right\}$ These rates of entry are low.

The effect of coughing was investigated as it was suspected that violent coughing may produce mixing of cisternal and lumbar cerebrospinal fluid, thus increasing the concentration of ${ }^{24} \mathrm{Na}$ in the lumbar region. However, Table VIII shows coughing between the first and second $5 \mathrm{ml}$. samples does not affect the concentration of ${ }^{24} \mathrm{Na}$ in the second sample.

Finally the effect of exercise during the test was investigated as it was thought that this might also produce mixing of cisternal and lumbar fluid. Two depressed patients were got out of bed and exercised by walking and touching their toes on numerous occasions. Both subsequently were found to have low rates of entry (Table VIII). Although it is possible that unexercised they would have had still lower rates of entry, it is clear that the higher rates of entry in the non-depressed patients could not be explained by any possible difference in their motility during the test. In fact all the patients cooperated by lying quietly during the time of the test and in no way approached the exercise undergone by these two patients.

\section{Discussion}

The rate of entry of sodium in the patients not suffering from a depressive illness-the controls, the schizophrenics, and patients who had recovered from a depressive illness-was slightly less but similar to that reported by other workers. Thus Benda, Planiol, Tubiana, and Constans (1954) in 15 normal adults found an average one-hour ratio of $6 \%$. Bourdillon, Fischer-Williams, Smith, and Taylor (1957) in a series of 20 patients suffering from a variety of conditions not involving a progressive disease of the nervous system found an average four-hour ratio of $30.1 \%$. From the data of Sweet et al. (1951), who followed the concentration of cerebrospinal fluid for four hours by frequent small samples, it is possible to deduce that the one-hour ratio of ${ }^{24} \mathrm{Na}$ is $1 / 5-1 / 6$ that of the four-hour ratio of ${ }^{24} \mathrm{Na}$. Thus this would give a one-hour ratio for the control subjects of Bourdillon et al. of approximately $5 \%$. Although none of the control group presented a picture of severe depression it should be pointed out that patients immediately before a major operation, sometimes after weeks of illness and pain, do inevitably show some degree of affective disturbance, which may account for the slower rate of entry of ${ }^{24} \mathrm{Na}$ compared with that in the controls of other workers.

It is clear that patients suffering from a depressive illness have a rate of entry of ${ }^{24} \mathrm{Na}$ almost half that of the other patients. It appears also that this slowing is a reversible phenomenon as patients who have recovered from a depression have normal rates of entry. The return to normal is related to the clinical state, rather than to the effect of E.C.T., for the group of patients who received E.C.T. but did not recover have the same entry rates as the patients with an untreated depression. 


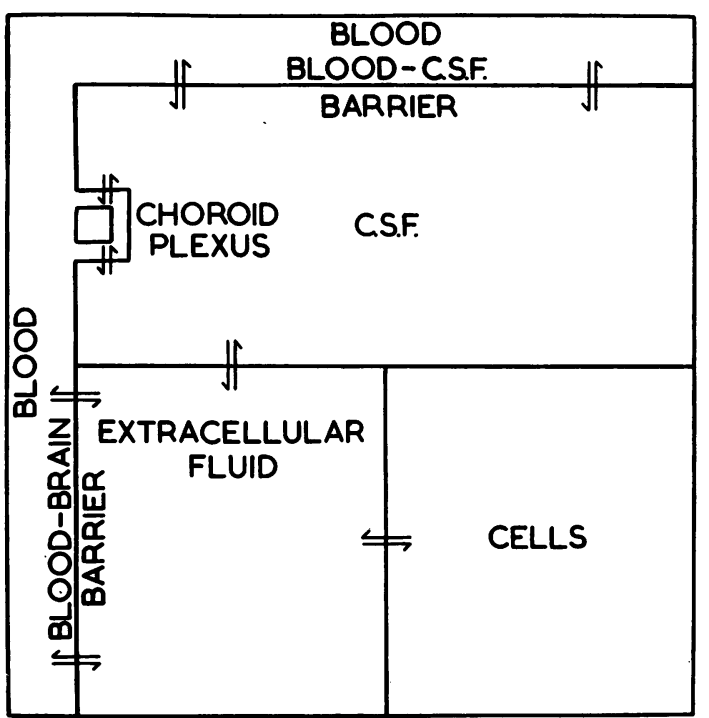

FIg. 2.-Possible pathways of ions into and out of cerebrospinal fluid from adjacent compartments of the central nervous system.

The possible pathways of ${ }^{24} \mathrm{Na}$ into and out of the cerebrospinal fluid are shown in Fig. 2. Factors affecting the concentration of ${ }^{24} \mathrm{Na}$ in cerebrospinal fluid one hour after its intravenous injection are complex, depending on its concentration in adjacent compartments of the central nervous system and the ease with which it can pass across the bloodbrain barrier into the extracellular fluid of the nervous system and across the blood-cerebrospinal fluid barrier into the fluid. ${ }^{24} \mathrm{Na}$ can also exchange between the extracellular fluid and the cerebrospinal fluid and also from the extracellular fluid to the nerve cells. Probably these two latter factors do not greatly affect the concentration of ${ }^{24} \mathrm{Na}$ in cerebrospinal fluid, as Davson (1955) and Crow (1955) have shown that ${ }^{24} \mathrm{Na}$ penetrates into the cerebrospinal and extracellular fluid at the same rate and also sodium is largely an extracellular ion.

There is good evidence that sodium penetrates into the lumbar cerebrospinal fluid from the blood at that level and does not arrive there by diffusion from the ventricles. Thus as Crow (1955) found in dogs, ${ }^{24} \mathrm{Na}$ appeared as rapidly in the lumbar region after the ventricular system had been blocked as before. Tubiana et al. (1951) found a normal rate of ${ }^{24} \mathrm{Na}$ entry in a patient with a complete spinal block. Selverstone (1958) found ${ }^{24} \mathrm{Na}$ injected into the lateral ventricle did not appear in the lumbar cerebrospinal fluid for some three hours, although Sweet et al. (1951) found ${ }^{24} \mathrm{Na}$ in the lumbar region some 20 minutes after its intravenous injection. It can be seen therefore that the rate of entry of
${ }^{24} \mathrm{Na}$ provides a measure of a vital physiological function, namely, the ease with which substances exchange between blood and the fluids of the nervous system in which the nerve cells function.

Ion transport across a membrane will depend on both the area and the permeability properties of the membrane. Thus the transfer of substances from the blood to nervous tissue will be influenced by vasomotor changes in the vascular bed as well as by changes in the permeability of the blood-brain barrier. Brierley (1952), in rabbits, found the considerable increase in penetration of ${ }^{32} \mathrm{P}$ that resulted from the inhalation of carbon dioxide could be accounted for by the increased blood flow within a dilated capillary bed. It was in order to obtain some measure of possible changes in the vascular area of the nervous tissue of depressed patients that the rate of tritium entry was measured. It has been shown by Bering (1952) and Sweet et al. (1951), and confirmed in the present investigation, that the exchange of water between blood cerebrospinal fluid is relatively free with little or no "barrier" effect. Therefore vasomotor changes should be reflected at least as much in the rate of penetration of tritium, where the size of the vascular bed is probably the most important factor limiting the rate of transfer, as in the case of sodium penetration which is influenced both by the size of the vascular bed and by a marked "barrier" effect. The results indicate that there is no significance in the tritium entry rate between depressed patients and patients who have recovered from a depression. The decrease in the rate of entry of sodium in depressed patients must therefore be due to a decrease in the permeability of the blood-cerebrospinal fluid barrier to sodium rather than to a decrease in the size of the capillary bed.

There is no doubt that the sodium ion has the greatest importance as far as the electrical activity of nerve cells is concerned (Hodgkin, 1951). For example, the resting potential of a nerve cell will vary according to the relative concentrations of sodium within the cell and outside, that is, in the extracellular fluid. Woodbury, Timiras, and Vernadakis (1957) here studied the effects of alterations in the transport of sodium within the central nervous system. Using the electro-shock seizure threshold as a measure of brain excitability, they have shown that this varies with alterations in sodium transport produced by adrenocortical steroids and other substances. Indeed there are numerous normally occurring substances that may be concerned with permeability and sodium transport; these include histamine, 5HT, posterior pituitary and adrenal cortical hormones, acetylcholine, and cholinesterase. 
Whether the changes in sodium entry are causal or secondary to the mental state only further experimental work can show. It is striking, however, that one procedure that increases the permeability of the blood-brain barrier, electroconvulsive therapy (Aird, 1958; Bjerner, Broman, and Swensson, 1944), is remarkably effective in improving the clinical state of a depressive illness.

\section{Summary}

The blood-cerebrospinal fluid barrier was investigated in mental patients by measuring the rate of entry of ${ }^{24} \mathrm{Na}$ from blood into cerebrospinal fluid. This was found to be normal in schizophrenia but the rate of entry was nearly half that of normal in patients suffering from a depressive illness. Patients who had recovered from a depressive illness had a normal rate of entry; the return to normal was related to clinical improvement as depressed patients who had received electro-convulsive treatment and had not improved were found to have a low rate of entry.

I should like to thank Dr. H. Davson for his most helpful suggestions and advice during the course of this investigation and Dr. G. F. M. Russell for his assistance in carrying out many of the tests.

\section{REFERENCES}

Aird, R. B. (1958). A.M.A. Arch. Neurol. Psychiat., 79, 633.

Benda, P., Planiol, T., Tubiana, M., and Constans, J. (1954). Radioisotope Conference, ed. J.'E. Johnston, Vol. 1, p. 161

Butterworth, London.
Bering, E. A. (1952). J. Neurosurg., 9, 275.

Bjerner, B., Broman, T., and Swensson, A. (1944). Acta psychiat. (Kbh.), 19, 431.

Bourdillon, R. B., Fischer-Williams, M., Smith, H. V., and Taylor, K. B. (1957). J. Neurol, Neurosurg. Psychiat., 20, 79.

Brierley, J. B. (1952). J. Physiol. (Lond.), 116, 24P.

Coppen A. J. (1959). J. Neurol. Neurosurg. Psychiat 22, 61.

Crow, H. J. (1955). Excerpta med. (Amst.), Sect. VIII, 8, 847.

Crow, H. J. (1955). Excerpta med. (Amst.), Sect.

(1956). Physiology of the Ocular and Cerebrospinal Fluids. Churchill, London.

, and Luck, C. P. (1959). J. Physiol. (Lond.), 145, 433.

Hodgkin, A. L. (1951). Biol. Rev., 26, 339.

Langham, W. H., Eversole, W. J., Hayes, F. N., and Trujillo, T. T. (1956). J. Lab. clin. Med., 47, 819

Mayer-Gross, W., Slater, E., and Roth, M. (1954). Clinical Psychiatry. Cassell, London.

Selverstone, B. (1958). In Ciba Foundation Symposium on the Cerebrospinal Fluid: Production, Circulation and Absorption, ed. G. Wolstenholme and C. M. O'Connor, p. 147. London.

Sweet, W. H., Selverstone, B., Soloway, S., and Stetten, D. (1951) American College of Surgeons, Surgical Forum, Philadelphia, 1950 , p. 376.

Tubiana, M., Benda, P., and Constans, J. (1951). Rev. Neurol., 85, 17.

Walter, F. K. (1929). Die Blut-Liquorschranke. Thieme, Leipzig.

Woodbury, D. M., Timiras, P. S., and Vernadakis, A. (1957). In Hormones, Brain Function, and Behavior, ed. H. Hoagland, p. 27. Academic Press, New York. 